GLOBAL JOURNAL OF EDUCATIONAL RESEARCH VOL 19, 2020 55-66

COPYRIGHT@ BACHUDO SCIENCE CO. LTD PRINTED IN NIGERIA. ISSN 1596-6224

55 www.globaljournalseries.com; Info@globaljournalseries.com

\title{
PLANNING SKILLS BY HEADS OF SCIENCE DEPARTMENT AND ACADEMIC PERFORMANCE IN SCIENCE SUBJECTS IN PUBLIC SECONDARY SCHOOLS IN NANDI COUNTY, KENYA
}

\section{ALFRED CHERUIYOT, VIVILINE NGENO AND JOASH K. KIBETT}

(Received 8, November 2019; Revision Accepted 18, December 2019)

\begin{abstract}
Curriculum and instructional planning is important to ensure that academic activities run without interruption in an academic year or term. Heads of departments (HODs of Science) play a pivotal role in implementation of curriculum in secondary schools. Planning is one of the functions vested on HODs to ensure proper implementation of curriculum in their departments. This paper therefore looks at HODs planning skills towards academic performance improvement in three science subjects in public secondary schools in Nandi County, Kenya. The decision to choose HODs of science was due to the importance that is placed on science subject but which has recorded below average performance compared to other subjects in Kenya Certificate of Secondary School. The three science subjects under investigation are; Physics, Biology and Chemistry for secondary schools. The study used mixed method research design. The study had three target populations that comprised of 231 heads of departments, 231 principals and 693 teachers. The sample size of the study was determined using Krejcie and Morgan formulae of determining sample size and comprised of 23 principals, 128 HODS of science and 247 teachers who were selected through stratified random sampling. Data collection was through questionnaires and interview schedule. Analysis of data was performed through quantitative and qualitative methods. The correlation analysis was computed from HODs and science teachers' data. The study discovered that most of them only planned for science practicals to be conducted on occasional basis by teachers in the department. Moreover, the HODs of Science ensured that the planned activities were conducted as planned. However, the HODs of Science were found not to have proper planning skills on ICT usage, acquisition of instructional material and conducting training needs assessment for teachers. The computed correlation statistics showed that there existed significant influence $(p<0.05)$ between planning skills by HODs of Science and academic performance of students in sciences in public secondary schools in Nandi County. The study recommends that HODs of Science need to be informed by Quality Assurance and Standards Officers (QASOs) that they need to be proactive and not reactive to the responsibilities under their docket. Participatory planning practices needs also to be embraced by HODs of Science for improved implementation and execution of set objectives and targets.
\end{abstract}

KEYWORDS: Planning, Skills, Quality, Performance, Sciences HODs

INTRODUCTION

Science education continues to have significant influence on quality of life of mankind and sustainable development of the world (UNESCO, 2004).

Science education equips man with the

Alfred Cheruiyot, Department of Educational Administration, Planning and Management, University of Kabianga, Kenya

Viviline Ngeno, Department of Educational Administration, Planning and Management, University of Kabianga, Kenya

Joash K. Kibett, Department of Horticulture (Agricultural Education), University of Kabianga, Kenya. 
knowledge and skills necessary to promote economic, scientific and technological development (Croxford, 2002). Therefore, more effort should be geared towards improving performance in science subjects (Biology, Chemistry and Physics). The performance of students in this subject in secondary schools is dependent on measures put in place to ensure that curriculum goals are attained in secondary schools. These measures can be accomplished through proper planning by those in charge like principals, heads of department and teachers.

Planning as a prerequisite for the achievement of goals, forms the basis of all other management tasks, and is thus about creating and designing regulated activities with a view to future needs. It reflects on the objectives of the school, the resources, as well as the activities involved, and involves drawing up the most suitable plan for achieving these objectives (Van Deventer \&Kruger, 2003). As managers, HOD's are responsible for planning the year's programme for their departments, lesson preparation, evaluation of teachers and professional development of teachers. Van Deventer and Kruger (2003) proposed that HODs of Science, in addressing these barriers, should take into consideration the following planning principles, which also calls for training: Planning should take place within the limits of the school's policy, revolving around teaching and learning; all aspects of planning should be related and in line with the plans of the school and consider human limitations, taking into account the workload of teachers and the amount of time learners need to complete assignments. Robbins and Coulter (2012) argue that it would be naive to conclude that planning was the sole cause of success in educational institutions because schools may be using other management practices such as organisational structure, good human resource practices or school culture to steer high performance. It is evident that there is an inherent knowledge gap in the relationship between planning skills and student academic performance. This paper looks at whether the planning skills of HODs of science influenced the academic performance of students in science subjects in public secondary schools in Nandi County, Kenya.

\section{PROBLEM STATEMENT}

Performance in national examinations in secondary schools nationally in science subjects has been on the decline. In Nandi County, for the last five years, the county has posted negative deviation in the academic mean scores in Biology and was relatively below the national mean. In 2016/2017 the chemistry percentage mean scores was below $50 \%$. In physics while the national percentage mean score was above average, the county mean was below $50 \%$ from 2015 to 2017 (CEB, 2017). Evidence from the Kenya National Examinations Council depicts the mean academic performance in Science subjects remained below average, (KNEC, 2017) in the last five years between (2013- 2017). In 2016 academic performance only $(28.36 \%)$ of the candidates in the county scored grade $\mathrm{C}+$ and above indicating that $71.64 \%$ of the students attained less than average grades (KNEC, 2017). The poor performance in science subjects across the country (Kenya) has become a major concern to the Government of Kenya and education stakeholders. The trend has been prevalent among the different schools. The poor performance curtails learners' chances to pursue science, engineering, technology and mathematics based careers. Various factors have been put forward to explain the poor performance of students in KCSE examinations in science subjects in secondary schools. However, limited studies have checked on the planning role that HODs perform and their influence on academic performance of students in science subject in public secondary schools in Nandi County and Kenya in particular.

\section{OBJECTIVE OF THE STUDY}

To investigate the influence of planning skills by heads of science department on academic performance in science subjects in public secondary schools in Nandi County, Kenya.

\section{RESEARCH HYPOTHESIS}

$\mathrm{HO}_{1}$. Planning skills of heads of science departments has no statistically significant influence on academic performance in science subjects in public secondary schools in Nandi County, Kenya.

$\mathrm{Ha}_{1}$. Planning skills of heads of science departments has statistically significant influence on academic performance in science subjects in public secondary schools in Nandi County, Kenya

\section{LITERATURE REVIEW}

Smith (2009) argues that most schools in England have long-term planning for the curriculum and textbook adoptions but rarely focus on the needs of the teachers and others who will implement those plans. Researchers 
over a decade have investigated the influence of strategic plans on organisational performance but to date; correlation between strategy and firm performance is an ongoing debate (Bolo, Muturia \& Oeba, 2010). Some authors argue that there is a minimal correlation between strategic plan and high organisational performance. Others posit that firms with well conceived and excellently executed plans have a high probability of high performance (Ansoff, 1990). Mazzarol (2009) from analysis of twelve research papers from 1950 's to 1980's indicated that planning was positively correlated with better performance. However, Wheelen and Hunger (2008) cautioned that some studies have found out that too much formalization of planning process may result in reduced performance. Planning in essence fails to focus on learners' achievements, to motivate teachers or to set clear goals. Anecdotal evidence depicts that although HODs of Science are involved in policy decisions they fail to implement them successfully. Barriers to effective planning also include fear for failure, lack of educational knowledge, lack of confidence, and resistance to change. According to Pearce and Robinson (2005) the planning process transcends the entire managerial activities including motivation, human relations, monitoring and control processes which entail cascading strategy to all functional areas in order to attain both vertical and horizontal logic and enhance organisational performance. Bottom and Schmidt-Davis, (2010) noted that the schools with the strongest emphasis on high expectations have succinct and powerful mission statements. Mission statements have become ubiquitous, but some schools have turned mission statements into school cultures that have motivated teachers and learners to perform effectively. Several studies have been conducted across the world to determine the contribution of HODs planning skills and academic performance of students in sciences from different countries.

In South Africa, Shonubi (2012) compared an effective school and ineffective school, in terms of how internal leadership and management of each school contribute its effectiveness. Data was collected from identified key role players within the two sampled schools. They include a school principal, vice-principal, Head of Departments (HOD), a teacher and classroom student leader (class captain) each, making-up a total of ten participants in the study - ( 5 from each school). It was found that School A was exceptional in terms of leadership and management practices compared to School B.
Although School A and B showed similar, but negligible characteristics in school planning, organising, management of change and; coordination of school teaching and learning, School A's strength in terms of management of the school, lies in its availability of school policy on teaching, decision-making, delegating, control, motivating, communicating, management of interpersonal relationships, school climate, culture, change, management of conflict and school school-community relationships. In Namibia, Muyoyeta, Abah and Denuga (2017) investigated school based factors affecting Grade 12 learners' academic performance in Senior Secondary Certificate Ordinary level (NSSCO) Biology. Mixed methods of Science research design involving both quantitative and qualitative approaches were used to collect data. A sample of 450 NSSCO Biology learners, 15 Biology teachers and 15 science HODs of Science were randomly selected to fill questionnaires. The findings further revealed that more HODs of Science $(40 \%)$ strongly agreed that the schools have enough Biology textbooks for each leaner and $27 \%$ of HODs of Science disagreed with the same statement. It was also found that more HODs of Science (53\%) disagreed that the school has sufficient laboratory equipment while $27 \%$ agreed with the same statement. When asked whether the school has a functional science laboratory, majority of HODs of Science (47\%) strongly agreed, $27 \%$ agreed and another $27 \%$ disagreed with the statement.

Muyoyeta (2018) investigated the factors that affect Grade 12 learners' academic performance in the Namibia Senior Secondary Certificate Ordinary (NSSCO) level Biology in the Khomas Educational Region, Namibia. Three categories of samples made up of 15 Science Heads of Departments (HODs of Science), 15 Biology teachers and 450 Grade 12 NSSCO Biology learners respectively were selected using the simple random sampling technique. All the HODs of Science (100\%) disagreed that Biology teachers are absent at least once every week. The table also showed that more HODs of Science $(53 \%)$ agreed that the teachers come late to lessons at least once a week while $33 \%$ disagreed. Furthermore, $67 \%$ of the HODs of Science agreed that the teachers leave the lesson to attend to other school works and only $33 \%$ HODs of Science disagreed with the same statement. In addition, $87 \%$ HODs of Science agreed that the teachers' attendance of Biology lessons sets a good example to the learners and only $13 \%$ disagreed with the statement. Jaca 
(2013) explored the leadership role of the Head of Department (HoD) in the teaching of Mathematics. A qualitative case study was employed whereby data were collected in two primary schools in Gauteng Province. Ten individual semi-structured interviews were conducted with four HODs of Science, two principals and four teachers in two township schools in a Gauteng district. Documents such as monitoring instruments of HODs of Science were also collected and analysed for purposes of triangulation. HODs of Science provided leadership by monitoring teaching and teachers' work, checking lesson plans, doing class visits, checking learners' books and assessment tasks and doing follow ups.

In Tanzania, Muchwe (2018) investigated factors that contribute to poor performance in science subjects among students in secondary schools in Tanzania. The study employed a cross-sectional research design whereby a total of 98 students from five schools in Kawe division were involved. Data collection was achieved through the use of questionnaires and structured interviews. Microsoft Office Excel and SPSS were the tools used to analyse the data collected. The main findings of this study showed that among many other reasons the common reasons that contribute to poor performance are poor methodology in science education, negative attitude towards science subjects among students and lack of resources such as text books and well equipped laboratories. Teachers should regularly attend the in-service training in order to equip themselves with new and modern methodology of teaching science subjects.

In Kenya, Oyier, Odundo, Ngaruiya and Mwangi (2017) study sought to establish the link between budgets planning in secondary schools in Nairobi County. A sampled principals and science teachers from public and private schools in Nairobi County were obtained using stratified sampling techniques. The study established that secondary schools have budgeting objectives that take science instructional resources in consideration; science teachers place their budgetary request based on their schemes of work to the budgeting committee and are present during prioritization on departmental list. Moreover, Oduol (2018) investigated factors that contributed to poor performance in science subjects among students in secondary schools in Busia County, Kenya. The input - output relationship or education production function was used. The study employed a cross - section research design whereby a total number of 110 students from six schools in the county, 15 students from three schools outside the county and 45 teachers were involved. Main findings of this study showed that factors which affect science subjects' performance are; poor methodology in science education, inadequate instructional material and physical facilities associated with poor planning. The gap created from Oduol study is that failure to indicate how HODs of Science planning skills affected provision of instructional materials and physical materials to ensure improved performance in science subjects, is the focus of this investigation.

\section{MATERIALS AND METHODS}

The study adopted a mixed method research design to investigate the influence of head of science departments' planning skills on students' academic performance in science subjects in Nandi County, Kenya. In this study the quantitative data was gathered using questionnaires pertaining to the research objectives of the study while qualitative data was collected from interviews and document checklist on the management practices of heads of science departments and how it influences academic performance in science subjects in public secondary schools. The basic assumption was that the combination of both quantitative and qualitative methods of Science provides a better understanding of the research problem, hypothesis and questions than either method by itself. The area of study was in Nandi County, Kenya. The target population consisted of 231 principals, 693 science teachers and 231 heads of science departments in 231 schools in Nandi County. The sample size was arrived through a statistical formular by Krejcie and Morgan (2004) for sample size determination

$$
s=\frac{X^{2} N P(1-P)}{d(N-1)+X^{2} P(1-P)}
$$

Results of computations are illustrated in Table 1 
Table 1: Sample Size Per Category

\begin{tabular}{|c|c|c|c|c|c|c|}
\hline \multirow[b]{2}{*}{ Category } & \multirow{2}{*}{$\begin{array}{l}\text { Principals } \\
\text { Target (N) }\end{array}$} & \multirow[b]{2}{*}{$\begin{array}{l}\text { Sample } \\
\text { (n) }\end{array}$} & \multicolumn{2}{|c|}{ HODs of Science } & \multirow{2}{*}{$\begin{array}{l}\text { Teachers } \\
\text { Target (N) }\end{array}$} & \multirow[b]{2}{*}{ Sample (n) } \\
\hline & & & Target (N) & Sample (n) & & \\
\hline National & 2 & 2 & 2 & 1 & 6 & 3 \\
\hline Extra County & 4 & 2 & 4 & 2 & 12 & 3 \\
\hline County & 60 & 5 & 60 & 33 & 180 & 66 \\
\hline Sub County & 165 & 14 & 165 & 92 & 495 & 175 \\
\hline Total & 231 & 23 & 231 & 128 & 693 & 247 \\
\hline
\end{tabular}

The principals, HODs and teachers were selected using stratified random sampling technique. The study used three research instruments to collect both quantitative and qualitative data namely: questionnaires, interview schedule and document analysis. Data collection was carried out by the researcher. Analysis of data was performed using descriptive; frequencies, percentages, means and standard deviation and inferential statistics; correlations were computed test the study hypotheses. Results and discussions are as presented below.

\section{RESULTS AND DISCUSSIONS}

The study was conducted among principals, heads of sciences and science teachers (Chemistry, Biology and Physics) in selected public secondary schools in Nandi County, Kenya. The researcher also asked the respondents to provide their highest level of professional qualifications. Results are given in Table

Table 2: Professional Qualification of Respondents

\begin{tabular}{lllllll}
\hline Professional qualifications & \multicolumn{2}{l}{ Principals } & \multicolumn{2}{c}{ HODs of Science } & \multicolumn{2}{c}{ Teachers } \\
& Freq & Percent & Freq & Percent & Freq & Percent \\
\hline Trained Diploma Teacher & 6 & 27.3 & 12 & 10.5 & 28 & 12.6 \\
Trained Graduate Teacher & 13 & 54.5 & 90 & 78.9 & 150 & 67.3 \\
Untrained Graduate Teacher & 0 & 0.0 & 3 & 2.6 & 16 & 7.2 \\
Postgraduate Teacher & 4 & 18.2 & 9 & 7.9 & 29 & 13.0 \\
\hline Total & $\mathbf{2 3}$ & $\mathbf{1 0 0 . 0}$ & $\mathbf{1 1 4}$ & $\mathbf{1 0 0 . 0}$ & $\mathbf{2 2 3}$ & $\mathbf{1 0 0 . 0}$ \\
\hline
\end{tabular}

Principal's responses on highest professional qualification level reveal that $6(27.3 \%)$ were diploma trained teachers, $13(54.5 \%)$ were trained graduate teachers while $4(18.2 \%)$ had post graduate qualification (post graduate diploma and masters). The result also depicts none of the principals were untrained graduate teachers. The findings depict that all the principals met the necessary threshold (diploma) to be recruited as teachers in secondary schools. Moreover, the Revised Teacher Career Progression Guidelines (2018) by TSC requires that for one to be appointed as a principal in secondary school, he/she must be a master's degree holder in relevant area. Nevertheless, the principals who have degree or diploma are the ones who were appointed long time ago before the amendment of the career progression guidelines.

Further, $90(78.9 \%)$ of HODs of Science were trained graduate teachers together with 150 $(67.3 \%)$ of science teachers. very few $3(2.6 \%)$ of
HODs of Science were found to be untrained and $16(7.2 \%)$ of science teachers. Moreover, 9 $(7.9 \%)$ had post graduate level of education same as $29(13.0 \%)$ of science teachers. the result therefore depicts that most science HODs of Science and teachers have met the minimum threshold required to be as teachers in secondary schools by TSC regulations. The remaining who are not trained are those who are still in school and perform their duties under the guidance of board of management of schools. The study result agrees with Nzoka and Orodho (2014) who found out that majority of the Heads of Departments $81.05 \%$ held university degrees. In addition, Oyier et al. (2017) found out that all science teachers were graduates with $8(9.50 \%)$ of them having post-graduate qualifications in Nairobi county. The implication of the findings reported in this section is that all schools in the study locale are staffed with human resource of acceptable and relevant academic qualification to teach science subjects in secondary schools. 
The study collected information on the performance of students in the three science subjects in secondary schools; Biology,
Chemistry and Physics. The highest grade to be attained is $A(12)$ and the lowest is $E$ (1).

The results are presented in Figure 1.

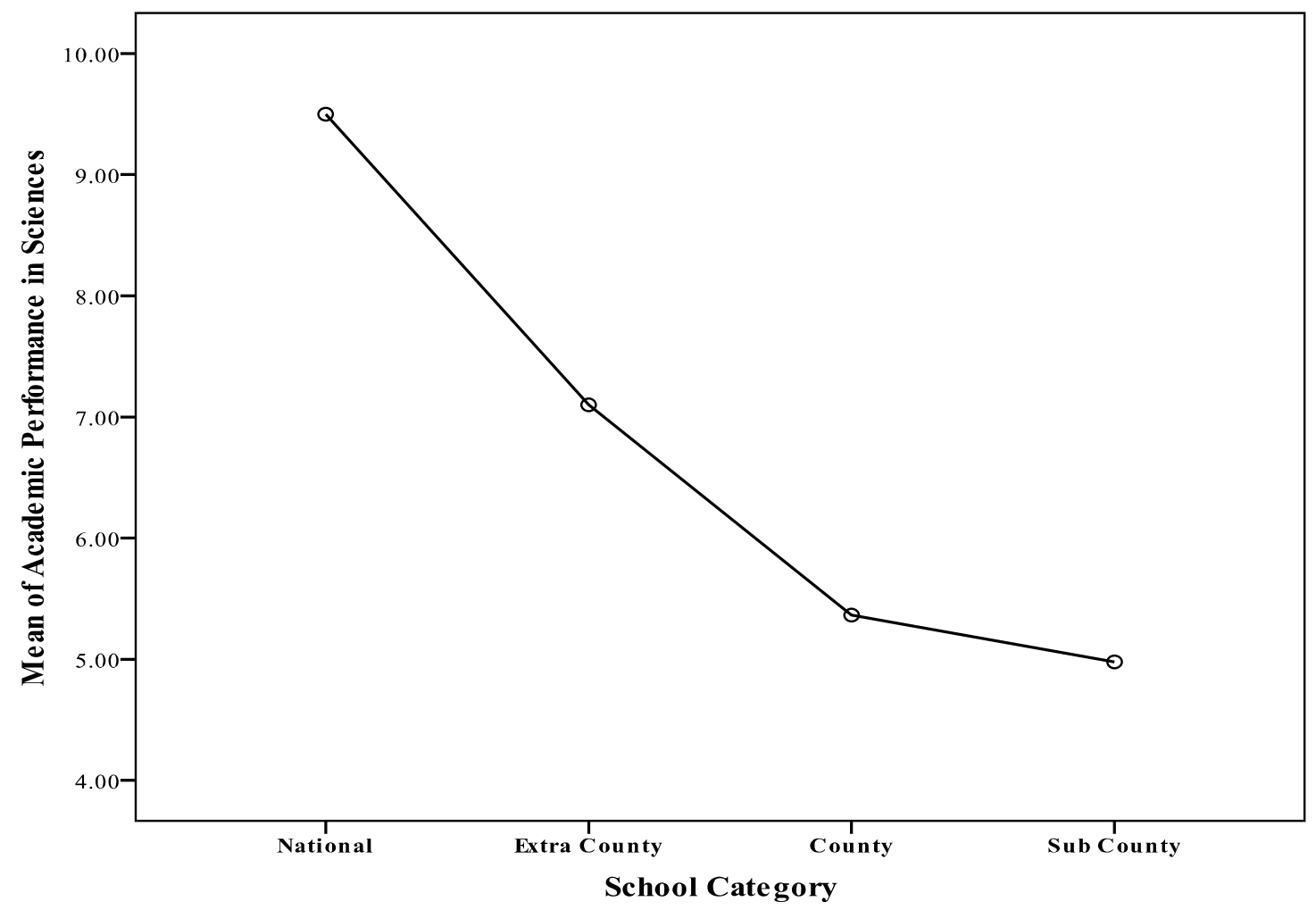

Figure 1 Performance in sciences across category of schools

The graph above depicts that the performance in science subjects in KCSE declines as the level of school category moves from national to sub county schools. Results indicate that national and extra county public secondary schools perform above average compared to county and sub county secondary schools whose performance is below average. A qualitative study done in Tanzania by Muchwe (2018) revealed 3 (50.0\%) HODs of Science said that the status of science performance in their schools was good while three others $(50.0 \%)$ said it was poor. This was due to reasons like availability of resources such as books and laboratory facilities. On the other hand, four heads of science departments said that science subjects are given special attention compared to other subjects in their schools while two said that the science subjects are not given any preference in their schools.
The objective of the study sought to establish the HODs of Science level of competency in planning and how it affected their students' academic performance in science subjects. The researcher sought views from principals of secondary schools, HODs of Science of sciences and science teachers from selected institutions in Nandi County, Kenya. Table 2 presents the descriptive results on the frequency to which HODs of Science rated their planning skills in comparison of teachers' responses. The questions were based on the application of the said planning skills by HODs of Science in secondary schools. The following scale was used; never (1.0-1.44), rarely (1.5-2.44), sometimes (2.5-3.44), often (3.5-4.44) and always

(4.5-5.0). 
Table 2: HODs of Science and Science Teachers Rating of Planning Skills by HODs of Science in Secondary Schools

\begin{tabular}{|c|c|c|c|c|c|}
\hline & \multirow{2}{*}{\multicolumn{2}{|c|}{$\begin{array}{l}\begin{array}{l}\text { Statements on HODs of Science } \\
\text { planning skills }\end{array} \\
\begin{array}{l}\text { HODs of } \\
\text { responses } \\
M\end{array}\end{array}$}} & \multirow{2}{*}{$\begin{array}{l}\text { Science } \\
\text { SD }\end{array}$} & \multicolumn{2}{|c|}{ Teachers responses } \\
\hline & & & & $\mathbf{M}$ & SD \\
\hline 1 & $\begin{array}{l}\text { Planning for acquisition of teaching / } \\
\text { learning materials }\end{array}$ & 4.3684 & .81211 & 3.3901 & 1.07187 \\
\hline 2 & $\begin{array}{l}\text { Planning on how to prepare lesson plans, } \\
\text { assessment and examinations with } \\
\text { teachers }\end{array}$ & 4.0526 & .97620 & 2.4126 & 1.03115 \\
\hline 3 & $\begin{array}{l}\text { Ensuring practical tasks in science subjects } \\
\text { are done as per schedule in collaboration } \\
\text { with the teachers }\end{array}$ & 4.5000 & .64149 & 4.2556 & .93102 \\
\hline 4 & $\begin{array}{l}\text { Planning and advising teachers on } \\
\text { integrating ICT in teaching of science } \\
\text { subjects }\end{array}$ & 3.3421 & .95777 & 3.0179 & 1.04392 \\
\hline 5 & $\begin{array}{l}\text { Setting timelines for achievement of targets } \\
\text { in the department }\end{array}$ & 4.0263 & .96359 & 4.0314 & .96511 \\
\hline 6 & $\begin{array}{l}\text { Effective in implementing the planned } \\
\text { activities }\end{array}$ & 4.1053 & .75690 & 2.4350 & 1.14846 \\
\hline 7 & $\begin{array}{l}\text { Collaborating with science teachers in } \\
\text { setting annual departmental plans that } \\
\text { focusing on improved student academic } \\
\text { performance }\end{array}$ & 4.4474 & .63930 & 3.4395 & 1.06317 \\
\hline \multirow[t]{2}{*}{8} & $\begin{array}{l}\text { Planning for teachers training based on a } \\
\text { thorough needs assessment for improved } \\
\text { academic performance }\end{array}$ & 2.8947 & 1.19267 & 2.3498 & .92200 \\
\hline & Average & 3.9671 & 0.8675 & 3.1665 & 1.0221 \\
\hline
\end{tabular}

Research findings show that HODs of Science agreed to often $(M=4.36$ and $S D=0.81)$ that they do plan for acquiring teaching aids in advance to ensure effective classroom instruction. However, science teachers had a different view by indicating that sometimes $(M=3.39$ and $S D=1.07)$ their HODs of Science plans for acquisition of learning materials and other times they do not. This means that not all times are instructional resource provision planned in advanced by HODs of Science and it could be due to their incapacity or the lack of provision by the school management. In a study conducted by Opiyo (2014), it was found out that HODs of Science were the least certain members in the school procurement committee. The study agrees with a study conducted by Muyoyeta (2018) who found out that More HODs of Science (40\%) strongly agreed that the schools have enough Biology textbooks for the learners while $27 \%$ of them disagreed with the same statement. When the instructional resources are not availed, effective curriculum implementation is hampered hence poor academic performance in sciences. The result further showed that few times are teachers involved in the procurement of instructional learning materials to be used during teaching process in classroom. The result may also suggest that procurement of materials is a responsibility of school management as teachers who are the key users end up being recipient. This means that even if teachers want specific learning materials to be availed to them, it solely depends on whether the school management will provide or not. They seem not to have a say in terms of making requests for specific learning materials to aid learning of sciences. This can be confirmed by Principal No. 1 who said that this is the procedure that is followed in their schools:

"HODs of Science prepare departmental budgets and place requisition on annual basis done in Nov/Dec of each year to the school board of management."

This means that once they prepare their material requirement for the preceding year, it is up to the school board of management or procurement committee to decide which resources would be availed or not.

Research revealed that HODs of Science claimed to be often ( $M=4.05$ and $S D=0.97)$ planned on how to prepare lesson plans, assessment and examinations with teachers in 
their departments. The result appears to be different from what science teachers reported where most often indicated that planning for lessons, methods of science subjects assessment are usually not inclusive in their schools $(M=2.41$ and $S D=1.03)$. This means that rarely do HODs of Science plan with teachers on how to prepare lesson plans, schemes of work, assessment methods and examination criteria in their departments. The result is in contrast to Ogina (2017) who established that most HODs of Science in South Africa planed together with teachers and agreed on how to draw up lesson plans, conduct assessments and examinations. They accomplished this by meeting every Thursday to discuss the challenges and success experienced by teachers in their various subjects. Through such meetings the HODs of Science also discussed submission due dates for lesson plans, files checklist, learners' books and portfolios. This is the approach and methods that HODs of Science of science in Nandi County public secondary schools need to apply for performance improvement in sciences.

Thirdly, the research result showed that HODs of Science agreed that they always $(M=4.5$ and $\mathrm{SD}=0.64$ ) ensured that practical tasks in science subjects are performed as per schedule in collaboration with teachers in the department whereas teachers of science said this often happened $(M=4.25$ and $S D=0.93)$. The result therefore depicts that as part of prior planning, HODs of Science ensure that many practicals are done to enable learners acquire the required competencies in science hence improved performance. However, the regularity of performing practicals depends on the availability of lab facilities and reagents in schools. In some sub county schools, there are no separate laboratories for Physics; Chemistry or Biology labs while others despite having the library have no resources required to perform certain experiments or tests. The result agrees with a study conducted by Muyoyeta (2018) who found out that at least $(53 \%)$ of HODs of Science disagreed with the statement that the school has sufficient laboratory equipment while $27 \%$ agreed with that lab resources were sufficient. This means that one challenge influencing effective conduction of practical in secondary schools is insufficient lab resources.

Research results also showed that HODs of Science $(M=3.34$ and $S D=0.95)$ and science teachers $(M=3.01$ and $S D=1.04)$ agreed that HODs of Science sometimes plan and advise teachers on the significance of integrating ICT in teaching of science subjects. This means that not all times are teachers reminded by HODs of Science of sciences to integrate ICT in teaching. This could be due to HODs of Science low level of competency in ICT usage or teachers lack of skills to handle the said ICT appliances in classroom or in some cases schools lack of these resources to facilitate learning. The result depicts that ICT planning has not yet taken root in majority of public secondary schools in Nandi County, Kenya. To confirm this outcome, Principal No. 22 had this to say:

"With regard to ICT, few are available in our institutions which make it difficult for science teachers to integrate it. There is no available support infrastructure to support ICT integration. In addition, lack of adequate teachers result to workload hence affecting ICT integration. Some science teachers lack skills."

This means that the problem of lack of proper planning on ICT is as a result of inability by HODs of Science but other deep rooted factors that are beyond their ability or position. Asked on whether HODs of Science set timelines for attainment of targets in the department, both HODs of Science $(M=4.02$ and $S D=0.96)$ and science teachers $(M=4.03$ and $S D=0.96)$ agreed that this happened often in their schools. The research therefore depicts that targets are set together with delivery times by HODs of Science in conjunction with science teachers. When targets are set with timelines to be realised, it ensures that interruptions, delays and noncompletion of activities are not experienced by schools. This would result to improved academic performance in sciences.

Sixthly, the study results show that HODs of Science agreed that often $(M=4.10$ and $S D=0.75)$ ensured that all planned activities were implemented whereas science teachers said that this practice by HODs of Science rarely happened $(M=2.43$ and $S D=1.14)$. One issue that is arising here is that majority of HODs of Science do not have the time and capacity to make follow up on ensuring that all planned activities have been implemented effectively. This could be due to high workload or even lack of desire by the HODs of Science to ensure that planned activities have been attained and to which level. Seventhly, research outcomes reveal that HODs of Science agreed that often $(M=4.47$ and $S D=0.63$ ) that they collaborate with teachers in setting out annual departmental plans whereas science teachers acknowledge that this kind of collaboration happened at times $(M=3.43$ and $S D=1.06)$. The result henceforth depicts that not 
all times do science teachers participate in setting up department plans aimed at setting performance targets for both tutors and students. This means that lack of effective collaboration may affect the implementation or attainment of performance measures due to lack of involvement of key stakeholders during planning phase. The study is different from Phalane (2016) who established that school management always involved and met regularly with teachers to discuss departmental goals and objectives.

Eighthly, research result indicate that HODs of Science said that often $(M=2.89$ and $S D=1.19)$ they had planning initiatives for teachers training based on needs assessment. With regard to the statement, the science teachers indicated this happened on rare occasions $(\mathrm{M}=2.34$ and $\mathrm{SD}=0.92$ ). The research result depicts that HODs of Science agree that they do not have the capacity to conduct needs analysis for their teachers either through lack of being given the mandate by their senior school management. In addition, when teachers are not asked to indicate the kind of training need they require, the training to be given may fail to meet their pedagogical content requirement. Composite data showed that HODs of Science rated their planning skills as high $(\mathrm{M}=3.96$ and $\mathrm{SD}=0.86)$ compared to science teachers who rated them as average $(M=3.16$ and $S D=1.02)$. The result henceforth depicts that half of the HODs of Science have the requisite planning skills to enable effective instructional process in public secondary schools in Nandi County.

\section{HYPOTHESIS TESTING}

The hypotheses for the study were:

$\mathrm{HO}_{1}$. Planning skills of heads of science departments has no statistically significant influence on academic performance in science subjects in public secondary schools in Nandi County, Kenya.

$\mathrm{Ha}_{1}$. Planning skills of heads of science departments has statistically significant influence on academic performance in science subjects in public secondary schools in Nandi County, Kenya To test the hypotheses for the study, a Karl Pearson correlation statistic was computed by using composite scores for HODs of Science and science teachers rating of HODs of Science planning skills against the academic performance in sciences (all three subject combined) of their students in previous KCSE examinations.

The results from science teachers are given in Table 3.

Table 3: Correlations on Teachers Ratings of HODs of Science Planning Skills and Academic Performance of Students in Sciences

\begin{tabular}{llll}
\hline & & Planning & Academic Performance \\
\hline Planning & Pearson Correlation & 1 & .540 \\
& Sig. (2-tailed) & & .000 \\
& $\mathrm{~N}$ & 223 & 223 \\
Academic & Pearson Correlation & $.540^{* *}$ & 1 \\
Performance & Sig. (2-tailed) & .000 & \\
& $\mathrm{~N}$ & 223 & 223 \\
\hline
\end{tabular}

${ }^{* *}$. Correlation is significant at the 0.01 level (2-tailed).

The correlation statistics in Table 3 depicts that at $99.0 \%$ confidence level, science teachers data reveal significant positive influence $(r=0.540$ \& $p=0.001$ ) of HODs of Science planning skills and academic performance of students in science subjects in public secondary schools in Nandi County. The null hypothesis is rejected $(p<0.025)$ and the alternative hypothesis is accepted leading to the conclusion that there exist significant positive influence of planning activities by HODs of science and academic performance in science subjects based on responses from science teachers. The correlation values are above average suggesting that the planning activities performed by HODs of Science have moderate positive impact on students' academic performance in science subjects. The statistics however suggests that application of planning strategies by HODs of Science consistently in their department would result to improved performance of students in science subjects in their schools. Similar to the study results, Katana (2015) finding showed that $93.3 \%$ of the respondents were to the view that planning competence was essential in the sense that it focused on learners' achievement.

Pearson correlation statistic was also computed for data collected from HODs of science. Results are given in Table 44. 
Table 4 Correlations on HODs of Science Planning Skills and Academic Performance of Students in Sciences

\begin{tabular}{llll}
\hline & & Planning Skills & Academic Performance \\
\hline Planning Skills & Pearson Correlation & 1 & .630 \\
& Sig. (2-tailed) & & .000 \\
Academic & $\mathrm{N}$ & 114 & 114 \\
Performance & Pearson Correlation & $.630^{* *}$ & 1 \\
& Sig. (2-tailed) & .000 & 114 \\
\hline${ }^{* *}$. Correlation is significant at the 0.01 level (2-tailed). & \\
\hline
\end{tabular}

Result shows that there exist significant positive influence of HODs of Science planning skills and academic performance $(r=0.630 \& p=0.001)$ of students in science subjects in public secondary schools in Nandi County, Kenya. The null hypothesis is rejected $(p<0.025)$ and the alternative hypothesis is accepted leading to the conclusion that there exist significant positive influence of planning activities by HODs of science and academic performance in science subjects based on responses from HODs of sciences. This implies that HODs of Science planning skills have significant positive influence on academic performance of students in science subjects in public secondary schools in Nandi County, Kenya. This means that HODs of Science continuous use of planning skills in their department would result to performance improvement in the three science subjects in schools.

Through interview, the principals were asked to give their views with regard to the contribution of HODs of Science planning skills and academic performance in science in public secondary schools. Principal No. 3 said that:

"Planning by HODs of Science in their department is critical in ensuring improved academic performance of students in sciences in secondary schools."

Another Principal No. 9 remarked that:

"Positively influence science subjects academic performance. This is because there is proper observance of time, early syllabus coverage and adequate provision of instructional resources."

Other principals said that their HODs of Science planning skills were fairly good while others indicated that their schools lacks strategic plan and this makes it impossible for their HODs of Science to do proper planning.

\section{CONCLUSIONS}

Study results showed that to a higher degree $(M=4.5$ and $S D=0.64)$ they always ensure that practical tasks are planned and scheduled in collaboration with teachers in schools. Science teachers corroborated this information from HODs of Science by indicating that there was so much emphasis on conduction of regular practicals and exercises in science subjects. In addition, the HODs of Science said that as part of planning, annual departmental plan setting is always done in collaboration. In contrast, the teachers reported that collaborating during setting annual departmental plans was sometimes participatory $(M=3.43$ and $S D=1.06)$. This means that not all schools had annual departmental plans except the ones developed for the whole schools or through institutions that have strategic plans. On the lower side of planning, the study found out that training needs assessment was rarely performed $(\mathrm{M}=2.34$ and $\mathrm{SD}=0.92$ ) as part of continuous professional development of teachers. Further, it was found out that acquisition of required instructional materials for teaching and learning of sciences was not all-inclusive and dependent on school senior management. Proper plans were also not found to be available to ensure full integration of ICT in teaching and learning of sciences in public secondary schools in Nandi County, Kenya. When testing the hypothesis, the computed pvalues were lower than the critical values leading to the deduction that planning skills by HODs of Science did significantly influence students' academic performance in and selected public secondary schools in Nandi County, Kenya. Despite average correlation values, most respondents were optimistic that better planning by HODs of Science would significantly lead to improvement in science subject performance in public secondary schools. Through proper HOD planning, it would result to increase in effectiveness of instructional tasks. It also ensures that the resources required are timely provided. In terms of time, the respondents said that proper HOD planning would result to reduction in wastage of time hence early syllabus coverage. 


\section{REFERENCES}

Ansoff, H., 1991. Implementing Strategic Management (2nd Ed.). Upper saddle River, NJ; Prentice Hall.

Bolo, Z.A. Muturia, J.M. and Oeba 2010. Strategic Planning Outcomes and Organisation performance: An empirical Study of commercial banks in Kenya. Research Journal in Organisational Psychology and Educational Studies.

Bottoms, G. and Schmidt-Davis, J., 2010. Actions for Transforming Schools. New York: McGraw Hill.

County Education Board 2017. Nandi County KCSE Results Report 2017. Kapsabet: Nandi County Director of Education Office.

Croxford, L., 2002. Participation in Science, Engineering and Technology at School and in Higher Education. Edinburgh: University of Edinburgh Centre for Educational Sociology.

Jaca, N.I., 2013. The leadership role of the Head of Department in the teaching of Mathematics. Masters Thesis, University of Pretoria, South Africa.

Katana, J.K., 2015. Impact Of Managerial Competencies Of Heads Of Departments On Students' academic Performance In Secondary Schools in Magarini Sub County, Kilifi County, Kenya. MED Project, University of Nairobi, Kenya.

Kenya National Examination Council 2017. Nandi County KCSE Result Report. Nairobi: KNEC.

Mazzarol, T. and Rebound, S., 2009. The strategy of small firm, strategic management and innovation in small firms.

Muchwe, J.K., 2018. Factors Contributing To Poor Performance of Science Subjects: A Case of Secondary Schools in Kawe Division, Kinondoni Municipality. Masters Dissertation, The Open University Of Tanzania.
Muyoyeta, N.K., 2018. Factors Affecting Grade 12 Learners' Academic Performance In The Namibia Senior Secondary Certificate Ordinary Level Biology In The Khomas Educational Region, Namibia. MED Thesis, The University Of Namibia.

Muyoyeta, N.K., Abah, J. and Denuga, D., 2017. School- Based Factors Affecting Grade 12 Learners' Academic Performance in Namibia Senior Secondary Certificate Ordinary level biology in the Khomas educational region, Namibia. International Journal of Education, Learning and Development, 5(7), $9-22$.

Nzoka, J.T. and Orodho, J. A., 2014. School Management and Students' Academic Performance: How Effective are Strategies being Employed by School Managers in Secondary Schools in Embu North District, Embu County, Kenya? International Journal of Humanities and Social Science, 4(9), 86 - 99.

Oduol, J.J., 2018. Factors Contributing To Poor Performance Of Science Subjects: A Case Of Secondary Schools In Busia County. Postgraduate diploma Dissertation, University of Nairobi, Kenya.

Ogina, T.A., 2017. How Heads of Departments Understand Their Roles as Instructional Leaders: A South African Study. Int J Edu Sci, 18(1-3), 224-230.

Opiyo, S.O., 2014. Influence Of Budgeting On Implementation Of Development Plans In Public Secondary Schools In Uriri District, Migori County, Kenya. MED Project, University of Nairobi.

Oyier, C. R., Odundo, P. A., Ngaruiya, B. and Mwangi, J., 2017. Science Teachers and Budget Planning for Instructional Resources in Secondary Schools in Nairobi, Kenya. Asian Education Studies, 2(3), $29-41$.

Pearce, II J.A and Robinson, R. B., 2005. Strategic Management: Planning for domestic and Global competition (13th Ed.). New York, NY: McGraw's Hill. 
Phalane, M. M., 2016. Leadership Strategies Employed By Secondary School Management Teams in Managing Teamwork in Tshwane North District Schools. D. Phil Dissertation, University of South Africa.

Robbins, S.P. and Coulter, M.A., 2012. Management (11th Ed.). New York: Pearson.

Shonubi, O.K., 2012. How leadership and management dynamics contribute to school effectiveness. PhD Thesis, University of Pretoria.
UNESCO 2004 Report on Development of Education in Kenya; Ministry of Education, Science and Technology. UNESCO-Nairobi Office.

Van Denveter, I. and Kruger, A.G., 2003. An Educator's Guide to School Management Skills. Pretoria: Van Schaik Publishers.

Wheelen, T.L. and Hunger, D.L., 2008. Strategic Management and Business Policy $\left(11^{\text {th }}\right.$ Ed.). New York: Pearson. 